\title{
Effect of Embryo Thermal Stimulation on the Serum Levels of Immunoglobulins and Corticosterone, and Organ Histopathology of 1 day-old Broilers
}

\section{mAuthor(s)}

\section{Flores $\mathrm{F}^{1}$}

Nääs IA'

Garcia RG"

Quinteiro WMQ"I

Souza LIV

College of Agricultural Engineering. The State University of Campinas, Ave. Cândido Rondon, 501, Postal Code 13083-875, Campinas, SP, Brazil

" College of Agrarian Sciences. The Federal University of Grande Dourados, Rod. Dourados Itahum, km, Postal Code 79822-020 Dourados, MS, Brazil

III SchoolofVeterinary Medicine and Animal Science, University of São Paulo.

iv PasReform do Brasil Tecnologias de Incubação, Rio Claro, SP

\section{ABSTRACT}

Embryo thermal stimulation has been studied as a means to promote epigenetic changes and to improve broiler health and performance. This study aimed at evaluating immunoglobulin ( $\lg M, \lg G$, and $\lg A$ ) titers, serum corticosterone levels, and organ integrity of day-old male Cobb $^{\circledR}$ and Ross ${ }^{\circledR}$ broilers. Embryos were submitted to hot and cold stimuli (thermal stimulation) on days 14-18 of incubation. The thermal manipulation treatments did not affect immunoglobulin titers of 1 dayold Cobb ${ }^{\circledR}$ or Ross ${ }^{\circledR}$ chicks, and caused severe bursal lesions (scores 3 and 4 ) in both strains. However, serum corticosterone levels of Cobb ${ }^{\circledR}$ chicks were higher when embryos were submitted to hot stimulus $\left(+1.39^{\circ} \mathrm{C}\right)$ compared with cold stimulus $\left(+36^{\circ} \mathrm{C}\right)$. Serum corticosterone levels of Ross $^{\circledR}$ chicks were not affected by embryo temperature manipulation. The only effect of broiler breeder age was observed on IgM titers of $\mathrm{Cobb}^{\circledR}$ chicks, which were higher in chicks from 33-wk-old breeders. Further studies are needed to detect the optimal period of embryo thermal stimulation.

\section{INTRODUCTION}

Commercial incubation plays a significant role in broiler production as it influences flock productivity, profitability, and broiler welfare. In this context, thermal stimulation during incubation has been studied as a means to increase the adaptability of broilers to heat and cold, i.e., to increase their efficiency to cope with temperature variations in the field (Moraes et al., 2003; Yalçin et al., 2008; Boerjan, 2010). According to Boerjan (2010), the imprinting of body functions increases production efficiency on farms.

However, thermal stimulation of the embryo may have deleterious effects. When exposed to high temperatures in the setter, embryos may release corticosterone, a hormone associated with stress, and produce more body heat. Consequently, embryo thermal stimulation should be applied within a narrow range of temperature.

In addition, during the first week of life, before the immune system starts to produce B lymphocytes, broiler humoral immunity depends on the maternal antibodies present in the egg yolk. Three classes of immunoglobulins are identified in domestic fowl, which are homologous to mammalian immunoglobulins (IgM, IgA, and $\lg \mathrm{G}$ ). Avian $\lg Y$ corresponds to mammalian lg $\mathrm{G}$ and $\lg \mathrm{E}$, and presents different functions: $\lg Y$ is the main defense mechanism against systemic infections (similar to mammalian $\mathrm{lg} G$ ) and also acts as a barrier that mediate anaphylactic reactions (similar to mammalian IgE) (Flores et al., 2013).The transfer of these immunoglobulins to the embryo and hatchling is influenced by breeder age, among other physiological mechanisms (Ulmer-Franco, 2012). Previous studies on the thermal stimulation of embryos during 
incubation (Yalçin et al., 2008; Piestun et al., 2008) did not evaluate its influence on mechanisms of maternal immunoglobulin transfer from the yolk to the embryo. Changes in incubation temperature may also cause lesions and atrophy of lymphoid organs and other tissues due to chronic stress.

Studies on the effect of excessive heat during incubation showed that embryos are able to adapt to high temperatures (Moraes et al., 2003; Yalçin et al., 2008), which may increase final embryo weight (Willemsen et al., 2008), and hatchability (Tzschentke \& Halle, 2009). However, there is a lack of research at commercial scale on the association of heat stress during incubation on incubation and live performance results and on the development of the immune system.

The objective of this study was to determine serum immunoglobulin titers and corticosterone levels, as well as to evaluate the tissue integrity of the organs of 1 day-old male chicks of two commercial broiler strains submitted to thermal stimulation between 14-18 days of embryo development.

\section{MATERIAL AND METHODS}

Fertile eggs of 32- to 53-wk-old of $\mathrm{Cobb}^{\circledR}$ breeders and of 61- to 63-wk-old Ross ${ }^{\circledR}$ breeders (Table 1) were submitted to variations in the incubation temperature during the last week of embryonic development (days 14-18 of incubation). Eggs were incubated in single-stage modular setter (SmartPro-77, Pas Reform
Hatchery Technology, Zeddam, The Netherlands) in a commercial hatchery located in the state of Rio Grande do Sul, Brazil. The setters were fully loaded $(76,800$ eggs) with eggs of both strains evaluated. Incubation temperature was weekly manipulated.

The eggs were subjected to three thermal treatments based on set points typically used by the hatchery (Table 2). Temperatures were changed as a function of temperature set point established for each day of embryonic development. The following treatments were applied: TM1 - temperature $+1.39^{\circ} \mathrm{C}$ higher than the daily temperature set points for three hours daily, returning to the set point at the end of this period, on days 14-18 embryonic development (ED); TM2 - temperature $+1^{\circ} \mathrm{C}$ higher than the daily set points for two hours daily, returning to the set point at the end of this period, on days 16-18 DE; and TM3 - temperature set at $36.00^{\circ} \mathrm{C}$, ranging between 1.00 and $0.30^{\circ} \mathrm{C}$ below the set daily points three hours daily (cold stimulus), returning to the set point at the end of this period, on 14-18 d of ED.

Two control treatments, which included eggs not submitted thermal stimulation and incubated in a single-stage setter, were established: PM1 - eggs from 61- to 63-wk-old Ross ${ }^{\circledR}$ breeders and PM2 - eggs from 32- to 53-wk-old $\mathrm{Cobb}^{\circledR}$ breeders. The number of eggs submitted to the treatments depended on the number of eggs from each strain available for incubation. $\mathrm{Cobb}^{\circledR}$ eggs were submitted to TM1, TM2, TM3, and

Table 1 - Description of treatments and incubation results

\begin{tabular}{|c|c|c|c|c|c|c|c|c|c|}
\hline $\begin{array}{l}\text { Number of } \\
\text { incubated eggs }\end{array}$ & $\begin{array}{l}\text { Days of } \\
\text { storage }\end{array}$ & $\begin{array}{l}\text { Thermal } \\
\text { treatment }\end{array}$ & $\begin{array}{l}\text { Age of female } \\
\text { breeders (wks) }\end{array}$ & $\begin{array}{l}\text { Genetic } \\
\text { strain }\end{array}$ & $\begin{array}{l}\text { Mean embryo } \\
\text { temp. }\left({ }^{\circ} \mathrm{C}\right)\end{array}$ & $\begin{array}{c}\text { Cloacal } \\
\text { temp. }\left({ }^{\circ} \mathrm{C}\right)\end{array}$ & $\begin{array}{l}\text { Hatchability of } \\
\text { fertile eggs (\%) }\end{array}$ & $\begin{array}{c}\text { Total } \\
\text { hatchability (\%) }\end{array}$ & $\begin{array}{c}\text { Fertility } \\
(\%)\end{array}$ \\
\hline 38.400 & 1 & TM2 & 53 & Cobb® & 38.80 & 35.89 & 84.18 & 81.15 & 96.39 \\
\hline 8.250 & 1 & TM2 & 48 & Cobb® & 38.80 & 36.94 & 88.52 & 85.95 & 97.09 \\
\hline 17.550 & 1 & TM2 & 36 & Cobb® & 38.80 & 36.68 & 90.57 & 89.57 & 98.89 \\
\hline 20.100 & 1 & TM3 & 35 & Cobb® & 38.17 & 37.47 & 89.18 & 88.35 & 99.25 \\
\hline 20.700 & 1 & PM2 & 34 & Cobb® & 38.46 & 37.53 & 89.69 & 87.98 & 98.09 \\
\hline 21.600 & 1 & TM1 & 33 & Cobb® & 38.87 & 37.03 & 89.71 & 84.45 & 98.59 \\
\hline 14.000 & 1 & TM1 & 61 & Ross® & 38.87 & 37.99 & 83.18 & 72.95 & 87.70 \\
\hline 14.850 & 1 & PM1 & 62 & Ross® & 38.46 & 37.13 & 80.03 & 67.54 & 84.39 \\
\hline 10.350 & 1 & TM3 & 63 & Ross® & 38.17 & 37.84 & 78.41 & 67.27 & 85.79 \\
\hline
\end{tabular}

$\mathrm{TM} 1=$ hot stimulus $\left(+1.39^{\circ} \mathrm{C}\right.$ for 3 h,days $14-18$ of embryo development); TM2= slight hot stimulus $\left(+1.00^{\circ} \mathrm{C}\right.$ for $2 \mathrm{~h}$, days $16-18$ of embryo development); $\mathrm{TM} 3=$ cold stimulus $\left(36.00^{\circ} \mathrm{C}\right.$ for $3 \mathrm{~h}$, days $14-18$ of embryo development); Control PM1= standard incubation temperature, Ross $\AA$ older breeders; Control PM2= standard incubation temperature, young Cobb® breeders).

PM2 treatments, and Ross ${ }^{\circledR}$ eggs, to $\mathrm{TM} 1, \mathrm{TM} 3$, and PM1 treatments.

At hatch, 15 male chicks from each treatment were randomly selected and sacrificed by cervical dislocation for blood and organ collection.
The experimental procedures complied with the Brazilian legislation on the ethical treatment of animals (Act n. 11.794 and Decree 6.899), and were approved by the Ethics Committee of the State University of Campinas (protocol number 3503-1). 
Table 2 - Thermal stimulation treatments.

\begin{tabular}{|c|c|c|c|c|c|c|c|c|c|c|c|c|}
\hline \multirow{3}{*}{$\begin{array}{l}\text { TM1 } \\
\text { Day-Hour } \\
\text { (h: min) }\end{array}$} & \multirow{3}{*}{ Temp $\left({ }^{\circ} \mathrm{C}\right)$} & \multicolumn{2}{|c|}{ TM2 } & \multicolumn{2}{|c|}{ TM3 } & \multicolumn{2}{|c|}{ PM1 } & \multicolumn{2}{|c|}{ PM2 } & \multicolumn{3}{|c|}{ Incubation conditions } \\
\hline & & \multirow{2}{*}{$\begin{array}{l}\text { Day-Hour } \\
\text { (h: min) }\end{array}$} & \multirow{2}{*}{ Temp $\left({ }^{\circ} \mathrm{C}\right)$} & \multirow{2}{*}{$\begin{array}{c}\text { Day-Hour } \\
\text { (h: } \min )\end{array}$} & \multirow{2}{*}{ Temp $\left({ }^{\circ} \mathrm{C}\right)$} & \multirow{2}{*}{$\begin{array}{c}\text { Day-Hour } \\
\text { (h: min) }\end{array}$} & \multirow{2}{*}{ Temp $\left({ }^{\circ} \mathrm{C}\right)$} & \multirow{2}{*}{$\begin{array}{c}\text { Day-Hour } \\
\text { (h: min) }\end{array}$} & \multirow{2}{*}{ Temp $\left({ }^{\circ} \mathrm{C}\right)$} & \multirow[t]{2}{*}{ UR (\%) } & \multirow{2}{*}{$\begin{array}{c}\mathrm{CO}_{2} \\
(\%)\end{array}$} & \multirow[t]{2}{*}{ Turning } \\
\hline & & & & & & & & & & & & \\
\hline $14-00: 00$ & 38.33 & 15-00:00 & 37.56 & 14-00:00 & 36.00 & 14-00:00 & 36.50 & 14-00:00 & 36.67 & 43 & 0.40 & 2 \\
\hline 14-00:03 & 36.67 & 15-00:02 & 36.56 & 14-00:03 & 36.67 & $15-00: 00$ & 36.39 & $15-00: 00$ & 36.56 & 42 & 0.40 & 2 \\
\hline $15-00: 00$ & 38.06 & $16-00: 00$ & 37.56 & $15-00: 00$ & 36.00 & $16-00: 00$ & 36.33 & $16-00: 00$ & 36.50 & 41 & 0.40 & 2 \\
\hline 15-00:03 & 36.56 & 16-00:02 & 36.50 & 15-00:03 & 36.56 & 17-00:00 & 36.22 & 17-00:00 & 36.44 & 40 & 0.40 & 2 \\
\hline $16-00: 00$ & 37.94 & $17-00: 00$ & 37.50 & $16-00: 00$ & 36.00 & 18-00:00 & 36.17 & $18-00: 00$ & 36.33 & 39 & 0.40 & 2 \\
\hline 16-00:03 & 36.50 & 17-00:02 & 36.44 & 16-00:03 & 36.50 & - & - & - & - & - & - & - \\
\hline $17-00: 00$ & 37.89 & 18-00:00 & 37.44 & 17-00:00 & 36.00 & - & - & - & - & - & - & - \\
\hline 17-00:03 & 36.44 & 18-00:02 & 36.33 & 17-00:03 & 36.44 & - & - & - & - & - & - & - \\
\hline $18-00: 00$ & 37.83 & - & - & $18-00: 00$ & 36.00 & - & - & - & - & - & - & - \\
\hline 18-00:03 & 36.33 & - & - & $18-00: 03$ & 36.33 & - & - & - & - & - & - & \\
\hline
\end{tabular}

$\mathrm{TM} 1=$ hot stimulus $\left(+1.39^{\circ} \mathrm{C}\right.$ for $3 \mathrm{~h}$, days $14-18$ of embryo development); $\mathrm{TM} 2=$ slight hot stimulus $\left(+1.00^{\circ} \mathrm{C}\right.$ for $2 \mathrm{~h}$, days $16-18$ of embryo development); TM3 $=$ cold stimulus $\left(36.00^{\circ} \mathrm{C}\right.$ for $3 \mathrm{~h}$, days $14-18$ of embryo development); Control PM1 = standard incubation temperature, Ross $®$ older breeders; Control PM2= standard incubation temperature, young $\mathrm{Cobb} \otimes$ breeders).

\section{Experimental procedures}

Setter environmental parameters (gas exchange, temperature, relative humidity, and egg turning) were recorded in real time during the entire incubation period, including the periods of thermal manipulation, using an information software system (SmartCenter ${ }^{\circledR}$, PasReform, Zeddam, The Netherlands), and the collected data are shown in Table 2. Eggshell surface temperature was measured in the setter trays (capacity of 150 eggs), duly identified according to treatment using an infrared thermometer (ITR 4520, Braun Termoscan ${ }^{\circledR}$, Kronberg, Germany) with an accuracy of $\pm 0.2^{\circ} \mathrm{C}$. Eggshell temperature was measured before and after temperature stimulation in the equatorial line of seven eggs per setter trolley position (low, middle, high), totaling 42 eggs per treatment per setter (21 in module 2 and 21 in module 3 of the setter). The infrared thermometer was calibrated and its precision was checked according to the manufacturer's instructions.

On day 19, eggs were transferred to the hatchers (SmartHatchPro ${ }^{\mathrm{TM}}$, Pas Reform Hatchery Technology, Zeddam, The Netherlands), with maximum capacity of 19,200 eggs each. Hatcher environmental parameters were automatically controlled by a software (SmartWatch ${ }^{\mathrm{TM}}$, Pas Reform Hatchery Technology, Zeddam, the Netherlands).

At hatch, chicks were feather-sexed, and 15 males per treatment and strain (identified according to basket) were selected and individually identified. Chicks were then sacrificed by dislocation of the first cervical vertebra, complying with the animal welfare standards established by the Brazilian Ministry of Agriculture (Act n. 11.794, as of October of 2008).Blood samples (vessels of the neck region) were collected in Eppendorf tubes for the determination of serum immunoglobulin titers and corticosterone levels.

The spleen, thymus, bursa, and heart were collected, and placed flasks containing 10\% formaldehyde for histopathology.

\section{Immunoglobulin analyses (IgM, IgG, IgA)}

Blood samples were kept on ice until clot retraction, and then centrifuged $\left(3220 \mathrm{~g}\right.$ for $15 \mathrm{~min}$ at $4{ }^{\circ} \mathrm{C}$ ) to collect the serum, which was stored in a freezer at -80 ${ }^{\circ} \mathrm{C}$ for a maximum of 30 days until immunoglobulin titration. $\lg A, \lg Y$, and $\lg M$ titers were determined using ELISA commercial kits (Bethyl Laboratories, Montgomery, TX, USA) as described by Quintero Filho et al. (2012). The kit precision limit was $15.62 \mathrm{ng} / \mathrm{mL}$, with a detection range of $15.62-1000 \mathrm{ng} / \mathrm{mL}$.

\section{Serum corticosterone analysis}

Serum corticosterone levels were chicks was determined using an ELISA (Enzyme-Linked Immunosorbent Assay) commercial kit (DetecteX ${ }^{\circledR}$ Corticosterone, ElA kit, Arbor Assays ${ }^{\circledR}$, Michigan, USA), as recommended by Quintero Filho et al. (2010). The kit presented a detection limit of $16.9 \mathrm{pg} / \mathrm{mL}$, with an interval of $16.9-10,000 \mathrm{pg} / \mathrm{mL}$.

\section{Histopathology analysis}

The collected organs were transversally sectioned in the midline, and the fragments were placed in 
lidded jars with $10 \%$ buffered formaldehyde. Organ fragments were dehydrated, cleared, embedded in paraffin, and sectioned to prepare the slides. Slides were stained with hematoxylin and eosin.

Tissue lesion intensity was determined on three different dates: blind samples (not identified samples, on the first two dates, and identified samples on the third date. Based on the lesions observed, organs were scored by an experienced pathologist for lesion intensity in a $0-3$ scale as: 0 , no lesions; $1(+)$, discrete lesions; $2(++)$, moderate lesions; and $3(+++)$ severe lesions.

The bursa was scored according to the degree of lymphoid depletions as: score 1: 0-25\%; score 2:2650\%; score 3: 51-80\%; score 4: $>81 \%$.In addition, acute (edema, inter-follicular infiltration of inflammatory cells, follicular cysts, hyperemia) and chronic lesions (fibroplasia) of the bursa were determined according to Muskett et al. (1979); Sterwart-Brown \& Trampel (1990), and Moraes et al. (2004).

\section{Statistical Analysis}

A randomized and observational experimental design was adopted. Chicks from 32- to 53-wk-old Cobb $^{\circledR}$ breeders were distributed into four treatments (three temperature manipulations and one control treatment); and chicks from 61- to 63-wk-old Ross ${ }^{\circledR}$ breeders were distributed into three treatments (two temperature manipulations and one control group).

Serum immunoglobulin and corticosterone results were submitted to analysis of variance using the GLM PROC, and means were compared by Tukey's test at a 95\% confidence level. Statistical analyses were performed using SAS statistical software $\left(S A S^{\circledR}\right.$ version 9.0, 2010).

\section{RESULTS AND DISCUSSION}

\section{Serum immunoglobulin and corticosterone levels}

No $\lg M, \lg G$, and $\lg A$ differences $(p>0.05)$ were observed between $\mathrm{Cobb}^{\circledR}$ chicks submitted to temperature manipulations during incubation or in the control group. However, the serum titers of all immunoglobulins of TM3 (cold stimulus, fixed at $36^{\circ} \mathrm{C}$ ) birds were higher compared with the other groups. TM1 (hot stimulus, $+1.39^{\circ} \mathrm{C}$ ) chicks presented lower IgM relative the other groups, whereas TM2 (slight hot stimulus, $+1^{\circ} \mathrm{C}$ ) chicks presented IgG levels compared with other groups. The IgA levels of all chicks submitted to thermal stimulation (TM1, TM2, and TM3) were higher than those of the control (no thermal stimulation) (Table 3).

Serum corticosterone levels of TM1 (hot stimulus, $\left.+1.39^{\circ} \mathrm{C}\right) \quad \mathrm{Cobb}^{\circledR}$ chicks were higher $(p<0.05)$ compared with $\mathrm{TM} 3$ (cold stimulus, $36^{\circ} \mathrm{C}$ ), but both were statistically similar to the control group. TM1 (hot stimulus, $+1.39^{\circ} \mathrm{C}$ ) chicks tended to present higher corticosterone levels than the control group, whereas TM3 (cold stimulus, $36^{\circ} \mathrm{C}$ ) birds, which tended present lower levels than the controls (Table 3 ). High corticosterone levels may stimulate or depress the immune system depending on the time and intensity of the stimulus that caused the change this hormone.

Immunoglobulin titers of $\mathrm{Cobb}^{\circledR}$ chicks were not different $(p>0.05)$ when comparing breeders before (33, 34, 35, 36 weeks old) and after (48 and 53 weeks) the peak of egg production. However, the highest IgM titer was obtained in chicks from 36-wk-old breeders, and the lowest, in chicks from 53-wk-old breeders, whereas no differences were found among the

Table 3 - Serum immunoglobulin titers and corticosterone levels (mean \pm standard error) of day-old Cobb ${ }^{\circledR}$ male chicks, according to thermal manipulation treatment and breeder age.

\begin{tabular}{|c|c|c|c|c|c|c|c|}
\hline & & $N$ & $\begin{array}{c}\mathrm{lgM} \\
\left(10^{3} \mathrm{ng} / \mathrm{mL}\right)\end{array}$ & $\begin{array}{c}\operatorname{lgG} \\
\left(10^{3} \mathrm{ng} / \mathrm{mL}\right)\end{array}$ & $\begin{array}{c}\operatorname{lgA} \\
\left(10^{3} \mathrm{ng} / \mathrm{mL}\right)\end{array}$ & $N$ & $\begin{array}{l}\text { Corticosterone } \\
\left(10^{3} \mathrm{ng} / \mathrm{mL}\right)\end{array}$ \\
\hline \multirow{4}{*}{ 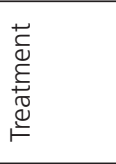 } & TM1 & 7 & $1.059 a \pm 0.021$ & $1415.459 a \pm 170.409$ & $3.934 a \pm 1.471$ & 7 & $60.661 \mathrm{a} \pm 8.539$ \\
\hline & PM2 & 7 & $1.110 \mathrm{a} \pm 0.021$ & $1354.009 a \pm 170.409$ & $3.099 a \pm 1471$ & 7 & $35.342 \mathrm{ab} \pm 8.540$ \\
\hline & TM3 & 7 & $1.150 a \pm 0.021$ & $1629.730 \mathrm{a} \pm 170.409$ & $8.539 a \pm 1.471$ & 13 & $18.738 \mathrm{~b} \pm 8.540$ \\
\hline & TM2 & 9 & $1.123 a \pm 0.018$ & $1177.319 a \pm 150.286$ & $4.413 a \pm 1.298$ & 7 & $34.744 a b \pm 6.266$ \\
\hline \multirow{6}{*}{ 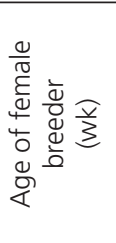 } & 33 & 7 & $1.059 \mathrm{ab} \pm 0.183$ & $1.415 a \pm 0.162$ & $3.934 a \pm 1.430$ & 7 & $60.661 \mathrm{a} \pm 7.983$ \\
\hline & 34 & 7 & $1.110 a b \pm 0.183$ & $1109.900 \mathrm{ab} \pm 162.192$ & $3.099 a \pm 2.184$ & 7 & $35.342 \mathrm{ab} \pm 7.983 .11$ \\
\hline & 35 & 7 & $1.149 a b \pm 0.184$ & $1629.730 \mathrm{a} \pm 162.193$ & $8.539 a \pm 0.014$ & 7 & $18.738 b \pm 7.983 .11$ \\
\hline & 36 & 3 & $1.811 \mathrm{a} \pm 279.600$ & $1415.459 a \pm 247.753$ & $3.934 a \pm 2.184$ & 5 & $17.983 b \pm 9.445 .74$ \\
\hline & 48 & 3 & $0.864 a b \pm 279.600$ & $1349.507 \mathrm{a} / 0.247$ & $5.165 a \pm 2.184$ & 4 & $37.013 a b \pm 10.561$ \\
\hline & 53 & 3 & $0.695 b \pm 279.600$ & $1440.570 \mathrm{a} \pm 247.753$ & $1.220 \mathrm{a} \pm 2.184$ & 4 & $5.3427 a b \pm 10.561$ \\
\hline
\end{tabular}

$\mathrm{TM} 1=$ hot stimulus $\left(+1.39^{\circ} \mathrm{C}\right.$ for $3 \mathrm{~h}$, days $14-18$ of embryo development); $\mathrm{TM} 2=$ slight hot stimulus $\left(+1.00^{\circ} \mathrm{C}\right.$ for $2 \mathrm{~h}$, days $16-18$ of embryo development); $\mathrm{TM} 3=$ cold stimulus $\left(36.00^{\circ} \mathrm{C}\right.$ for 3 h, days $14-18$ of embryo development); Control PM2= standard incubation temperature, Cobb ${ }^{\circledast}$ breeders).

Values followed by different letters in the same columns are different by Tukey's test $(p<0.05) ; N=$ number of samples. 
other evaluated breeder ages (Table 3). Chicks from the different breeder ages were different $(p<0.05)$; however, the age pattern detected by Tona et al. (2004) (Table 3). When contrasting breeder age with thermal treatment, it is observed that the temperature stimulation not the only factor causing the increase in serum corticosterone levels.

In Ross ${ }^{\circledR}$ chicks, no IgM, IgG, or IgA titer differences ( $p>0.05$ ) were observed between those submitted to thermal stimulation and the control group. However, $\operatorname{lgM}$ and $\lg \mathrm{G}$ titers of $\mathrm{TM} 1$ (hot stimulus, $+1.39^{\circ} \mathrm{C}$ ) chicks were higher compared with TM3 (cold stimulus, $36^{\circ} \mathrm{C}$ ) and the control group, and a trend of $\lg \mathrm{A}$ reduction in the thermally-stimulated groups relative to the control group (no thermal stimulation) (Table 4). Serum corticosterone levels of Ross ${ }^{\circledR}$ chicks were not different ( $p>0.05$ ) among treatments; however, TM1 and TM3 chicks tended to present lower levels than the control chicks (no thermal stimulation) (Table 4).

Broilers exposed to high environmental temperature present immune changes, including T-cell and naturalkiller cell counts, cytokine secretion, lymphocyte proliferation, and immunoglobulin titers (Quintal-Filho et al., 2010, 2012). However, in the present experiment, immunoglobulin titers did not significantly increase when chicks were submitted to hot stimuli during incubation. This variation in immunoglobulin titers may be due to intrinsic or extrinsic factors not related to incubation, as well as to maternal characteristics.

Serum corticosterone levels of Ross ${ }^{\circledR}$ chicks were not affected ( $p>0.05)$ by temperature manipulation during incubation. On the other hand, in $\mathrm{Cobb}^{\circledR}$ chicks, corticosterone levels were influenced $(p<0.05)$ by treatment and breeder age, as shown in Table 3 . TM1 chicks (hot stimulus, $+1.39^{\circ} \mathrm{C}$ ) from 33-wk-old breeders presented the highest level. This suggests Cobb $^{\circledR}$ embryos from young breeders may experience stronger heat stress. Chick corticosterone levels increased with breeder age (Table 3), suggesting that corticosterone release is affected by stress factors other than those evaluated in the present study.
Tona et al. (2004) evaluated the incubation of three broiler strains and observed differences in embryo corticosterone levels, triiodothyronine/thyroxine (T3/ T4) ratio, and heat production and suggested that the embryo metabolic rate can be used as an indicator of post-hatch performance. These results are consistent with other published studies by this group (Tona et al., 2003) demonstrating that the embryos with higher levels of physiological indicators, such as corticosterone, present better post-hatch development.

Other studies have shown heat-production differences between layer and broiler strains (Nangsuay et al., 2011), as well as among broiler breeds and strains (Tona et al., 2010). According to Lourens et al. (2007), embryo heat exchange directly influences its metabolism. Different heat production by embryos incubated at the same temperature indicate differences in embryo temperature due to differences in metabolism, which makes it difficult to estimate heat exchange.

It is well established that serum corticosterone levels are directly related to stress intensity (Voslarova et al., 2011), and therefore, should be determined when evaluating the effects of thermal stress. Moreover, corticosterone is also a critical endogenous factor affecting overall embryo metabolism and behavior (Tong et al., 2013). According to Quinteiro-Filho et al. (2010) and Tong et al. (2013), high corticosterone levels reduce yolk sac absorption rate as well as the weight of bursa, thymus, and spleen, predisposing to lower immunity.

Rodricks et al. (2006) reported that glucocorticoids are essential for energy metabolism, and regulate several neurotransmitter receptors in broilers, and showed that a sharp increase in embryo corticosterone levels due to hypoxia impairs chick memory at hatch. Hypoxia stimulates the hypothalamic-pituitary-adrenal (HPA) axis, induces the release of corticosterone, which, in high levels, interacts with catecholamines (epinephrine and norepinephrine) to increase glucose levels, heart rate and blood pressure.

Table 4 - Immunoglobulin titers and serum corticosterone levels (mean \pm standard error) of day-old Ross ${ }^{\circledR}$ male chicks, according to thermal manipulation treatment and breeder age.

\begin{tabular}{|c|c|c|c|c|c|c|c|c|}
\hline & & $\mathrm{N}$ & $\begin{array}{c}\operatorname{lgM} \\
\left(10^{3} \mathrm{ng} / \mathrm{mL}\right)\end{array}$ & $\begin{array}{c}\operatorname{lgG} \\
\left(10^{3} \mathrm{ng} / \mathrm{mL}\right)\end{array}$ & $\mathrm{N}$ & $\begin{array}{c}\operatorname{lgA} \\
\left(10^{3} \mathrm{ng} / \mathrm{mL}\right)\end{array}$ & $\mathrm{N}$ & $\begin{array}{c}\text { Corticosterone } \\
\left(10^{3} \mathrm{ng} / \mathrm{mL}\right)\end{array}$ \\
\hline \multirow{3}{*}{ 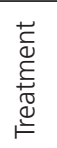 } & TM1 & 7 & $857.8 a \pm 132.31$ & $1755116 a \pm 165572.10$ & 8 & $5066 a \pm 2743.10$ & 7 & $31276 a \pm 5359.85$ \\
\hline & TM3 & 7 & $847.7 a \pm 132.31$ & $1665380 \mathrm{a} \pm 165572.10$ & 7 & $3422 \mathrm{a} \pm 2932.50$ & 7 & $16872 \mathrm{a} \pm 5789.30$ \\
\hline & PM1 & 7 & $825.2 \mathrm{a} \pm 132.31$ & $1310879 a \pm 165572.10$ & 7 & $7249 a \pm 2932.50$ & 6 & $31106 a \pm 5359.85$ \\
\hline
\end{tabular}

$\mathrm{TM} 1=$ hot stimulus $\left(+1.39^{\circ} \mathrm{C}\right.$ for $3 \mathrm{~h}$, days $14-18$ of embryo development); $\mathrm{TM} 3=$ cold stimulus $\left(36.00^{\circ} \mathrm{C}\right.$ for $3 \mathrm{~h}$, days $14-18$ of embryo development); Control PM2= standard incubation temperature, Ross $®$ breeders).

Values followed by different letters in the same columns are different by Tukey's test $(p<0.05)$; $N=$ number of samples 


\section{Histopathology}

The chicks from $\mathrm{Cobb}^{\circledR}$ and Ross ${ }^{\circledR}$ broiler breeders of different ages and submitted to thermal stimulation or not, presented similar tissue lesion scores (Table 5). Bursal lesions scores of 3-4 were determined in all chicks, independently of embryo thermal treatment, whereas chicks of the control treatments did no present any lesions. The observed bursal lesions presented similar characteristics as those caused by the infectious bursal disease (IBD) virus (Murmu et al., 2014) both from vaccine and field strains. It should be noted that organs were collected immediately after hatch, and birds had not been vaccinated against IBD yet. Immunosuppression is directly related to the integrity of the bursal tissue. Studies reporting bursal tissue lesions caused IBD vaccine viruses showed that they may induce similar or even more severe lesions than field viruses (Michell, 2009). The bursal lesions found in the present study are consistent with those reported in poultry with immunosuppressive diseases, including lymphoid depletion and necrosis, intermolecular inflammatory infiltration, edema, and hyperemia.

Further studies should be carried out with broilers subjected to temperature manipulation during embryonic development to verify if such lesions are healed during the rearing period, if they are indeed caused by embryo temperature manipulation, and their performance and health status are compromised in the field.

According to Gilberts \& Epel (2009), short-time variations in incubation environment induce gene expression changes, resulting in different phenotypic responses to environmental factors. Embryoenvironment interaction can lead to epigenetic adaptation. In poultry, the most widely studied environmental factor influencing epigenetic adaptation is the exposure of embryos to short-term high or low temperatures. Broiler embryos are more sensitive to thermal adaptation in early incubation, when their tissues and organs are being formed, and again at a later stage of development, when the organs and physiological systems mature, which was used in the present study (days 14-18 of embryonic development). Tzchentke (2007) and Tzchentke \& Halle (2009) reported that short-term temperature manipulation of broiler embryos during the four last days of incubation, when the thermoregulatory system is well developed, and therefore, more responsive to "training", promotes the long-term adaptation of broilers in the field.

According to Lourens et al. (2005), the eggshell temperature of chicken embryos should be $37.78^{\circ} \mathrm{C}$ between the first day of incubation until transfer to the hatcher. The technical recommendation of singlestage incubators is $38.33^{\circ} \mathrm{C}$ during the last three days of incubation (Pas Reform, 2010ab).

The measured eggshell temperatures are presented in Table 1 and Figure 1. The graphs ( $A$ and $B$ ) show that eggshell temperature changed during temperature manipulation, but returned to the recommended temperature in a short time and did not exceed maximum and minimum limits.

Embryo thermal conditioning during specific phases induces long-term adaptation, promoting positive effects on post-hatch broiler performance (Moraes et al., 2003; Maltby et al., 2004; Yalçin et al., 2008; Piestun et al., 2008, 2013; Shinder et al., 2009). However, embryo thermal conditioning is only beneficial if incubation temperature manipulation is strictly controlled in terms of temperature range, time, and duration (Tzschentke, 2007).

Table 5 - Histological results of the bursa, thymus, heart and spleen.

\begin{tabular}{|c|c|c|c|c|}
\hline \multirow{3}{*}{ Genetic strain } & \multirow{3}{*}{ Treatment } & \multicolumn{3}{|c|}{ Results } \\
\hline & & \multirow[b]{2}{*}{ Score } & \multicolumn{2}{|l|}{ Lesions } \\
\hline & & & Bursa & Organs (thymus, heart, and spleen) \\
\hline \multirow{3}{*}{$\mathrm{Cobb} \circledast$} & TM1 and TM2 & 3 & $\begin{array}{l}\text { Depletion and lymphoid necrosis of } 51-80 \% \text {, infiltrated } \\
\text { interfollicular inflammatory, edema, and hyperemia }\end{array}$ & Congestion \\
\hline & TM3 & 4 & $\begin{array}{l}\text { Depletion and lymphoid necrosis }>81 \% \text {, infiltrated } \\
\text { interfollicular inflammatory, edema, and hyperemia }\end{array}$ & Moderate to severe congestion. \\
\hline & PM2 - control & & Absence of lesions & \\
\hline \multirow{3}{*}{ Ross $®$} & TM1 & 3 & $\begin{array}{l}\text { Depletion and lymphoid necrosis of } 51-80 \% \text {, infiltrated } \\
\text { interfollicular inflammatory, edema, and hyperemia }\end{array}$ & Congestion \\
\hline & TM3 & 3 & $\begin{array}{l}\text { Depletion and lymphoid necrosis of } 51-80 \% \text {, infiltrated } \\
\text { interfollicular inflammatory, edema, and hyperemia }\end{array}$ & Moderate to severe congestion. \\
\hline & PM1 - control & & Absence of lesions & \\
\hline
\end{tabular}

$\mathrm{TM} 1=$ hot stimulus $\left(+1.39^{\circ} \mathrm{C}\right.$ for $3 \mathrm{~h}$, days $14-18$ of embryo development); $\mathrm{TM} 2=$ slight hot stimulus $\left(+1.00^{\circ} \mathrm{C}\right.$ for $2 \mathrm{~h}$, days $16-18$ of embryo development); $\mathrm{TM} 3=$ cold stimulus $\left(36.00^{\circ} \mathrm{C}\right.$ for $3 \mathrm{~h}$, days $14-18$ of embryo development); Control PM1 = standard incubation temperature, Ross $₫$ older breeders; Control PM2= standard incubation temperature, young Cobb $®$ breeders). 

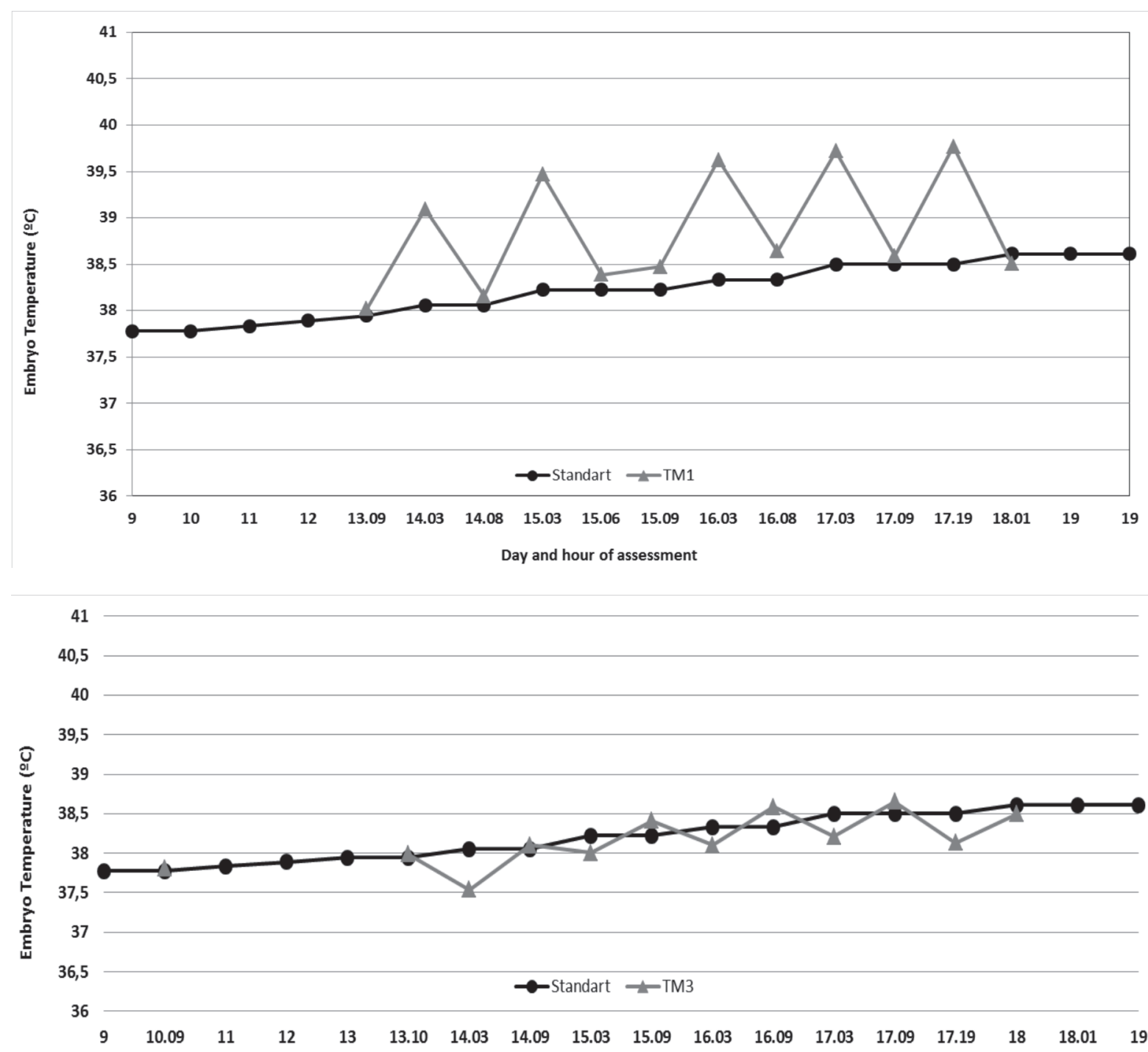

Day and hour of assessment

Figure 1 - Eggshell temperatures measured before and after thermal stimulation. $\mathrm{TM} 1=$ hot stimulus $\left(+1.39^{\circ} \mathrm{C}\right.$ for $3 \mathrm{~h}$, days $14-18$ of embryo development); $\mathrm{TM} 2=$ slight hot stimulus $\left(+1.00^{\circ} \mathrm{C}\right.$ for $2 \mathrm{~h}$, days $16-18$ of embryo development); $\mathrm{TM} 3=$ cold stimulus $\left(36.00^{\circ} \mathrm{C}\right.$ for $3 \mathrm{~h}$, days $14-18$ of embryo development).

The positive or negative response of broilers in field to embryo temperature manipulation depend on embryo age at the time it is applied (Leksrisompong et al., 2009). Therefore, the performance of flocks of broilers submitted to thermal manipulation during incubation is essential to determine the efficiency of this process.

\section{CONCLUSIONS}

The thermal manipulation treatments applied to embryos on days 14-18 of incubation did not affect immunoglobulin titers of day-old $\operatorname{Cobb}^{\circledR}$ or Ross ${ }^{\circledR}$ chicks, and caused severe bursal lesions in both strains. However, serum corticosterone levels of $\mathrm{Cobb}^{\circledR}$ chicks were higher when embryos were submitted to hot stimulus $\left(+1.39^{\circ} \mathrm{C}\right)$ compared with cold stimulus $(+36$ $\left.{ }^{\circ} \mathrm{C}\right)$. Serum corticosterone levels of Ross ${ }^{\circledR}$ chicks were not affected by embryo temperature manipulation.

The only effect of broiler breeder age was observed on IgM titers of $\mathrm{Cobb}^{\circledR}$ chicks, which were higher in chicks from 33-wk-old breeders.

Further studies are recommended to elucidate how embryo thermal stimulation influences the studied factors.

\section{REFERENCES}

Boerjan M. Circadian incubation.InternationalHatcheryPractice2010;24:13 -15 . 
Flores F, Nääs IA, Garcia GR. Variação térmica durante a incubação de ovos e seus efeitos sobre os componentes imunológicos do embrião. Enciclopédia Biosfera 2013;9(17):2594-2612.

French NA. Managing the incubation environment in commercial hatcheries to meet the requirements of the embryo. Avian and Poultry Biology Reviews 2002;13(3):179-185.

French NA. Modeling incubation temperature: The effects of incubator design, embryonic development, and egg size. Poultry Science 1997;76:124-133.

Gilbert SF, Epel D. Ecological developmental biology: integrating epigenetics, medicine and evolution. Massachusetts: Sinauer Associates; 2009

Leksrisompong N, Romero-Sanchez H, Plumstead PW, Brannan KE, Yahav $\mathrm{S}$, Brake J. Broiler incubation-2. Interaction of incubation and brooding temperatures on broiler chick feed consumption and growth. Poultry Science 2009;88(6):1321-1329.

Lourens A, Van Den Brand H, Heitkamp MJW, Meijerhof R, Kemp, B. Effects of eggshell temperature and oxygen concentration on Embryo growth and metabolism during incubation. Poultry Science 2007;86:2194-2199

Lourens A, Van Den Brand H, Meijerhof R, Kemp B. Effect of eggs shell temperature during incubation on embryo development, hatchability, and post-hatch development. Poultry Science 2005;84:914-920.

Maltby $\mathrm{V}$, Somaiya, A, French, NA, Stickland NC.In ovo temperature manipulation influences post-hatch muscle growth in the turkey. British Poultry Science 2004;45:491-498.

Michell BC, Gomes AD, Baião NC, Resende M, Lara LJC, Martins NRS.Effect of maternally-derived antibodies on the performance and immunity of broilers induced by in ovo or post-hatching immunizations with a live vaccine against infectious bursal disease. Brazilian Journal of Poultry Science 2009;11(1):57-63.

Moraes HLS, Salle CTP, Padilha AP, Nascimento VP, Souza G F, Pereira RA, Artencio JO, Salle FO.Infectious bursal disease: evaluation of pathogenicity of commercial vaccines from brazil in specific pathogen free chickens. Brazilian. Journal of Poultry Science 2004;6(4):243-247.

Moraes VMB, Malheiros RD, Bruggeman V, Collin A, Tona K, Van As P, et al. Effect of thermal conditioning during incubation embryo development on aspects of physiological responses of broilers to heat stress. Journal of Thermal Biology 2003;28:133-140.

Murmu R, Islam N, JuliBS, Khan AS, Rashid HSM, Hossain FMA, et al. Pathogenicity and immunosuppressive properties of GM-97 strain of infectious bursal disease virus in commercial broiler chickens.Journal of Advanced Veterinary and Animal Research 2014;1(1):1-7.

Muskett JC, Hopkins IG, Edwards KR, Thornton DH.Comparison of two infectious bursal disease vaccine strains : Efficacy and potential hazards in susceptible and maternally immune birds. Veterinary Record 1979;104:332-334

Nangsuay A, Ruangpanit Y, Meijerhof R, Attamangkune S. Yolk absorption and embryo development of small and large eggs originating from young and old breeder hens. Poultry Science 2011;90:2648- 2655.

Pás ReformHatchery Technologies. Publicações Técnicas. Departamento de Pesquisa e Desenvolvimento. Academia de incubação - Putting Science IntoPractice. 2nded. Zeddan, The Netherlands; 2010a.

Pas ReformHatchery Technologies. Incubation guide - Frango de corte. Version 4.1. Zeddan, The Netherlands; 2010b

Piestun Y, Shinder D, Ruzal M, Halevy O, Brake J, Yahav S. Thermal manipulations during broiler embryogenesis:Effect on the acquisition of thermotolerance. Poultry Science 2008;87:1516-1525.
Quinteiro-Filho WM, Ribeiro A,Ferraz-de-Paula V, Pinheiro ML, Sakai M, Sá LR, et al. Heat stress impairs performance parameters, induces intestinal injury, and decreases macrophage activity in broiler chickens. Poultry Science 2010;89(9):1905-14.

Quinteiro-Filho WM, Rodrigues MV, Ribeiro A, Ferraz-de-Paula V, Pinheiro $M L$, SálR, et al. Acute heat stress impairs performance parameters and induces mild intestinal enteritis in broiler chickens: role of acute hypothalamic-pituitary-adrenal axis activation. Journal of Animal Science 2012;90(6):1986-94

Rodricks CL, Millerb SL, Jenkinb G, Gibbs ME. The role of Corticosterone in prehatch-induced memory deficits in chicks. Brain Research 2006;1123:.34-41.

SAS Institute. SAS ${ }^{\circledR}$ user's guide: statistics. 9.2 version. Cary; 2010

Shinder D, Rusal M, Giloh M, Yahav S. Effect of repetitive acute cold exposures during the last phase of broiler embryogenesis on cold resistance through the life span. Poultry Science 2009;88:636-646.

Stewart-Brown, B., Trampel, D. W. Quantitatin glymphocyte depletion of thymus and bursa using an image processing technique. Proceedings of Western Poultry Disease Conference1990;105-107.

Tona K, Onagbesan O, De Ketelaere B, Decuypere E, Bruggeman V. Effects of turning duration on corticosterone and thyroid levels, gas pressures in air cell, chick quality, and juvenile growth. Poultry Science 2003:82:1974-1979.

Tona $K$, Onagbesan $O$, Jego $Y$, Kamers $B$, Decuypere $E$, Bruggeman $V$. Comparison of embryo Physiological parameters during incubation, chick quality, and growth performance of three lines of broiler breeders differing in genetic composition and growth rate. Poultry Science 2004;85:507-513

Tona K, Onagbesan O, Kamers B, Everaert N, Bruggeman V, Decuypere E. Comparison and Cobb e Ross strains in embryo physiology and chick juvenile growth. Poultry Science 2010;89:1677-1683.

Tong Q, Romanini CE, Exadaktylos V, Bahr C, Berckmans D, BergougEH, et al. Embryonic development and the physiological factors that coordinate hatching in domestic chickens. Poultry Science 2013;92:620-628.

Tzschentke B, Halle I. Influence of temperature stimulation during the last 4 days of incubation on secondary sex ratio and later performance in male and female broiler chicks. British Poultry Science 2009;50(5):634640.

Tzschentke, B. Attainment of thermoregulation as affected by environmental factors (Conference Paper). Poultry Science 2007;86(5):1025-1036.

Ulmer-Franco AM, Cherian G, Quezada N, Fasenko GM, Mcmullen LM. Hatching egg and newly hatched chick yolk sac total IgY content at broiler breeder flock ages. Poultry Science 2012;91:758-764.

Voslarova E, Chloupek P, Vosmerova P, Chloupek J, Bedanoval I, Vecerek $V$. Time course changes in selected biochemical indices of broilers in response to pretransport handling. Poultry Science 2011;90(10):21442152.

Willemsen H, Everaert N, Witterg A, De Smit L, Debonne M, VerschuereF, et al. Critical assessment of chick quality measurements as an indicator of post-hatch performance. Poultry Science 2008;87:2358-2366.

Yalçin S, Çabuk M, BruggemanV, Babacanoglu E, Buyse J, Decuypere E, et al. Acclimation to heat stress during incubation:1. Effects on embryonic morphological traits, blood biochemistry, and hatching performance. Poultry Science 2008;87:1219-1228. 